\title{
Faktor Risiko Asma Pada Murid Sekolah Dasar Usia 6-7 Tahun di Kota Padang
}

\author{
Afdal, ${ }^{*}$ Finny Fitry Yani, ${ }^{*}$ Darfioes Basir, ${ }^{*}$ Rizanda Machmoed, ${ }^{* \star}$
}

\section{Abstrak}

Latar belakang : Asma merupakan penyakit kronik yang sering dijumpai pada anak. Dilaporkan bahwa prevalens asma meningkat pada anak maupun dewasa. Usia 6-7 tahun merupakan periode dimana prevalens asma dan angka kunjungan ke rumah sakit karena asma lebih tinggi. Terjadinya asma dianggap sebagai interaksi yang kompleks antara faktor genetik dan faktor lingkungan. Faktor genetik sudah dibuktikan dari penelitianpenelitian sebelumnya, tetapi karakteristik faktor risiko lingkungan pada asma belum jelas. Apabila melihat derajat peningkatan kejadian asma, tidak mungkin hanya faktor genetik yang berperan, tetapi peran faktor lingkungan justru yang lebih besar. Tujuan : Untuk mengetahui prevalens dan faktor risiko asma pada anak SD usia 6-7 tahun di Kota Padang.Metoda : Suatu penelitian cross sectional di 20 SD di Kota Padang pada bulan Juni - November 2009 dengan jumlah sampel 879 orang. Terhadap setiap subjek dilakukan penelitian yaitu pembagian kuisioner ISAAC (international study of asthma and allergies in childhood) untuk orang tua. Analisis data dilakukan dengan uji chi-square untuk variabel katagorik dan analisis multivariat dengan regresi logistik. Data dianalisis menggunakan peranti lunak komputer.Hasil : Prevalens asma pada murid SD usia 6-7 tahun di Kota Padang berdasarkan kuisioner ISAAC sebesar $8 \%$. Faktor yang paling dominan berpengaruh terhadap kejadian asma adalah atopi ayah atau ibu, diikuti faktor berat badan lahir dan kebiasaan merokok pada ibu serta pemberian obat parasetamol. Sedangkan pemberian ASI dan kontak dengan unggas merupakan faktor protektif terhadap kejadian asma.

Kata kunci: faktor risiko, asma, sekolah dasar

\section{Abstract}

Background: Background Asthma is a common chronic disease in children. It had been reported that the prevalence of asthma in children and adults was increasing. The age of 6-7 years is the period where the prevalence and the number of visits to the hospital because of asthma are higher. The occurrence of asthma is considered as a complex interaction between genetic factors and environmental factors. Genetic factors have been proved to be the risk factor for asthma, but not for the characteristic of environmental that factors that were still unclear. If seeing the increased incidence of asthma, genetic factors might not play a role solely, but the environmental factors might play moreObjective The aim of this study was to determine the prevalence and the risk factors of asthma in elementary school children aged 6-7 years in Padang.Methods This research is cross sectional study in 20 elementary schools in Padang during June until November 2009, total sample of 879 students. To each respondent the ISAAC (international study of asthma and allergies in childhood) questionnaire was given to be fulfilled. Data were analyzed using computer software. Results The prevalence of asthma in elementary school students aged 6-7 years in Padang based on ISAAC questionnaire was $8 \%$. The most dominant factor influencing the incidence of asthma is atopic in father or mother, followed by factors of birth weight and maternal smoking habits and drug administration of paracetamol, while breastfeeding and poultry contact were protective factors.

Keywords:risk factors, asthma, elementary school

Affiliasi penulis : *Bagian IImu Kesehatan Anak Fakultas Kedokteran Universitas Andalas Padang, ${ }^{* *}$ Bagian IImu Kesehatan Masyarakat Fakultas Kedokteran Universitas Andalas Padang.

Korespondensi : Afdal, Bagian IImu Kesehatan Anak Fakultas Kedokteran Universitas Andalas Padang. afdaldr@yahoo.com Telp: 0751-37913

\section{Pendahuluan}

Asma merupakan penyakit kronik yang sering dijumpai pada anak dan mengalami peningkatan angka kejadian yang sangat drastis dalam kurun waktu terakhir.Laporan dari Inggris menyebutkan bahwa insiden asma meningkat pada semua kelompok umur, terutama pada balita. Pada balita insiden asma dari tahun 1976 meningkat 11 kali lipat pada tahun 1993, yaitu antara $10-20$ menjadi sekitar 150 kasus per 100.000 balita. ${ }^{1}$ Berdasarkan laporan center for disease control (CDC) tahun 2000 mengenai prevalens asma pada anak usia $<18$ tahun sebelum dan sesudah tahun 1997 di Amerika Serikat, terlihat adanya peningkatan prevalens asma sebesar 5\% setiap tahun dari tahun 1980 sampai $1995 .^{2}$

Tingkat prevalens asma yang cukup besar menjadi masalah kesehatan masyarakat yang serius.Di Amerika Serikat, pada tahun 1998, terdapat 166.000 kasus rawat inap karena asma, sehingga asma merupakan penyebab rawat inap jangka pendek terbesar.Pada tahun 1995, biaya untuk pengobatan asma mencapai 250 juta dollar AS, sedangkan penghitungan kehilangan hari sekolah, aktifitas atau biaya lain bisa mencapai 1,2 milyar dollar AS, belum lagi biaya akibat hilangnya waktu kerja orang tua untuk mengurus anaknya, dan penderita asma dapat mengalami keterbatasan dan penurunan kualitas hidup yang serius. ${ }^{3}$

Penelitan International Study of Asthma and Allergies in Childhood (ISAAC) merupakan suatu penelitian cross-sectional multifase terbesar terhadap epidemiologi asma, rinitis alergi dan dermatitis alergi 
yang pernah dilakukan dengan cara memfasilitasi kolaborasi international. Penelitian ini ditujukan untuk anak usia 6-7 tahun karena pada usia ini prevalens asma terbesar dan usia 13-14 tahun karena mortalitas asma paling tinggi pada usia tersebut.,

Terdapat beberapa faktor risiko lingkungan yang dikompilasi dari penelitian ISAAC dan penelitianpenelitan lain yang telah dilakukan untuk diikutkan dalam ISAAC fase III yang sudah mulai dilakukan, yaitu risiko obesitas, mengkonsumsi makanan tidak dominan sayuran, mengkonsumsi makanan cepat saji, kurang olah raga, memasak menggunakan gas atau minyak tanah, sering menggunakan parasetamol, pemberian antibiotik sebelum berusia satu tahun, jumlah saudara, pendidikan ibu tinggi, rumah dekat lalu lintas, berat badan lahir rendah, tidak diberi ASI, alergen (anjing dan kucing), dan orang tua perokok. Dasar mekanisme beberapa faktor risiko ini sudah juga mulai diteliti dan diduga berhubungan dengan sensitisasi dini, hygiene hyphothesis dan kadar antioksidan, sedangkan beberapa yang lain baru murni bersifat epidemiogik. ${ }^{4,5}$

Beberapa makanan yang sering dikaitkan dengan kejadian asma dan umum dikonsumsi seharihari di masyarakat adalah coklat, es dan monosodium glutamat (MSG)..$^{6-10}$ Kontak dengan unggas dan paparan terhadap debu rumah yang dapat dipicu oleh memakai kipas angin, dan karpet serta memakai kasur kapuk juga umum didapatkan di masyarakat dan sering dikaitkan dengan kejadian asma. ${ }^{11}$

Tujuan penelitian ini adalah untuk mengetahui prevalens asma pada anak sekolah dasar usia 6-7 tahun di Kota Padang dan mengidentifikasi faktor-faktor lingkungan yang berperan sebagai faktor risiko asma.

\section{Metode Penelitian}

merupakan suatu penelitian cross sectional di beberapa SD di Kota Padang yang dilaksanakan pada bulan Juni - November 2009.

\section{Populasi dan sampel}

Populasi penelitian adalah semua anak SD usia 6-7 tahun yang bertempat tingal di Kota Padang dengan orang tua mereka sebagai responden. Sampel penelitian adalah semua murid kelas I dan II dan berusia 6-7 tahun dari SD terpilih dengan carasimple random sampling. Kriteria inklusi adalah anak di SD terpilih yang duduk dikelas I dan II dan berusia 6-7 tahun pada saat penelitian, orang tua hadir pada saat pembagian kuisioner dan bersedia ikut dalam penelitian.Kriteria eksklusi adalah tidak mengisi kuisioner penelitian secara lengkap.Didapatkan 879 responden dari 20 SD yang memenuhi kriteria inklusi dan ekslusi.

\section{Pengumpulan data}

Pengumpulan data dengan cara responden diundang datang ke sekolah dan pengisian kuisioner dilakukan pada saat itu memakai kuisiner ISAAC yang sudah dimodifikasi.Sebelum pengisian kuisioner seluruh subjek penelitian diberikan penjelasan mengenai penyakit asma secara umum, dan gejala klinis asma yang harus dikenali diantaranya; mengi, batuk, sesak, serta mengenai rinitis dan penyakit eksim.Selama pengisian kuisioner responden didampingi oleh peneliti untuk menjelaskan hal-hal yang belum dimengerti pada waktu penjelasan umum tersebut. Responden diberi kesempatan untuk bertanya jika ada hal atau pertanyaan yang tidak dimengerti

\section{Identifikasi variabel}

Variabel terikat pada penelitian ini adalah kejadian asma dan variabel bebasnya adalah status gizi, jumlah saudara, pendidikan ibu, berat badan lahir, faktor diet, berupa konsumsi makanan cepat saji dan kurang makan sayuran, konsumsi coklat, es dan MSG, pemberian ASI, obat, yaitu pemberian parasetamol dengan frekuensi tinggi dan pemberian antibiotika saat sebelum usia satu tahun, paparan alergen bulu anjing dalam 12 bulan terakhir dan 12 bulan pertama kehidupan, paparan alergen bulu kucing dalam 12 bulan terakhir dan 12 bulan pertama kehidupan, kontak dengan unggas dalam 12 bulan terakhir, kebiasaan orang tua merokok, olah raga/aktifitas keseharian, bahan bakar memasak, faktor lingkungan rumah, yaitu lingkungan dengan paparan lalu lintas, memakai kipas angin, karpet dan kasur kapuk dalam 12 bulan terakhir. Sedangkan yang menjadi variabel pengganggu adalah riwayat atopi pada orang tua.

\section{Definisi operasional}

Asma adalah adanya nafas mengi, suara nafas berbunyi ngik-ngik atau bengek dalam 12 bulan terakhir. Atopi adalah pernah mengalami gejala salah satu atau lebih dari asma, rinitis alergi, atau eksim.Status gizi ditentukan dari pengukuran Indeks Massa Tubuh (IMT) yang dihitung berdasarkan rumus berat badan (dalam $\mathrm{kg}$ ) dibagi kuadrat tinggi badan (dalam m). Konsumsi makanan cepat saji (western food) adalah western food yang berhubungan dengan asma atau alergi adalah: mentega atau susu atau lemak dari binatang memamah biak, atau diet makanan cepat saji/burger sebanyak "tiga kali atau lebih seminggu." Konsumsi makanan kurang sayuran adalah diet dengan dasar sayuran yang kurang, ditentukan dengan tidak pernah atau jarang atau kadang-kadang yaitu "tidak lebih dari satu hingga dua kali seminggu" memakan buah-buahan atau sayuran atau biji-bijian atau sereal, kacang, kentang, dan sering yaitu "tiga kali atau lebih seminggu" makan daging atau mentega atau susu atau telur.

\section{Hasil}

Selama periode penelitian dari bulan Juni November 2009 di 20 Sekolah Dasar di Kota Padang didapatkan subjek penelitian sebanyak 933 orang. Lima puluh empat orang drop out karena tidak mengisi kuisoner dengan lengkap, sehingga didapatkan jumlah sampel penelitan sebesar 879 orang.

Persentase jenis kelamin subjek penelitian tidak jauh berbeda antara laki-laki dengan perempuan (50,1\% banding $49,9 \%$ ). Sebagian besar status gizi subjek penelitian berada pada kategori normal yaitu sebanyak 601 orang $(68,4 \%)$ (tabel 1$)$. 
Tabel 1. Karakteristik dasar subjek penelitian $(n=879)$

\begin{tabular}{|c|c|c|}
\hline Karakteristik & Jumlah & Persentase \\
\hline \multicolumn{3}{|l|}{$\begin{array}{ll}\text { - } & \text { Jenis } \\
\text { kelamin }\end{array}$} \\
\hline Laki-laki & 440 & 50,1 \\
\hline & 439 & 49,9 \\
\hline \multicolumn{3}{|l|}{ Perempuan } \\
\hline \multicolumn{3}{|l|}{ 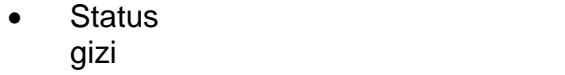 } \\
\hline \multirow{4}{*}{$\begin{array}{c}\text { Underweight } \\
\text { Normal }\end{array}$} & 224 & \\
\hline & & 25,5 \\
\hline & 601 & 68,4 \\
\hline & 34 & \\
\hline \multirow{2}{*}{$\begin{array}{l}\text { Overweight } \\
\text { Obesitas }\end{array}$} & & 3,9 \\
\hline & 20 & 2,3 \\
\hline
\end{tabular}

Hasil penelitian memperlihatkan berdasarkan kuisioner ISAAC didapatkan prevalens asma sebesar $8,0 \%$ (70 dari 879 orang).

Hubungan faktor atopi orang tua dengan kejadian asma

adanya atopi ayah, atopi ibu, atopi ayah atau ibu merupakan faktor yang bermakna untuk timbulnya asma $(p<0,05)$, tetapi adanya atopi pada kedua orang tua (ayah dan ibu) secara statistik tidak merupakan faktor yang bermakna terhadap kejadian asma $(p>0,05)$ (tabel 2).

Tabel 2. Hubungan faktor riwayat atopi orang tua dengan kejadian asma $(n=879)$

\begin{tabular}{|c|c|c|c|c|c|c|c|c|}
\hline \multirow{2}{*}{ No } & \multirow{2}{*}{ Variabel } & \multicolumn{2}{|c|}{ Asma } & \multicolumn{2}{|c|}{ Tidak asma } & \multirow{2}{*}{ p } & \multirow{2}{*}{ OR } & \multirow{2}{*}{$\mathrm{Cl}$} \\
\hline & & $\mathrm{n}$ & $\%$ & $\mathrm{n}$ & $\%$ & & & \\
\hline \multirow[t]{2}{*}{1} & $\begin{array}{l}\text { atopi } \\
\text { ayah }\end{array}$ & & & & & 0,000 & 3,18 & $1,72-5,85 k$ \\
\hline & $\begin{array}{l}\text { - Ada } \\
\text { - Tidak } \\
\text { ada }\end{array}$ & 16 & 18,8 & 740 & $\begin{array}{l}81,2 \\
93,2\end{array}$ & & & \\
\hline \multirow[t]{2}{*}{2} & Atopi ibu & & & & & 0,000 & 5,22 & $3,14-8,68 b$ \\
\hline & - Ada & 33 & 21,9 & 118 & 78,1 & & & \\
\hline \multirow[t]{3}{*}{3} & $\begin{array}{l}\text { - Tidak } \\
\text { atopi }\end{array}$ & 37 & 5,1 & 691 & 94,9 & & & \\
\hline & $\begin{array}{l}\text { ayah } \\
\text { atau ibu }\end{array}$ & & & & & 0,000 & 7,1 & $4.21-11.96$ \\
\hline & - Ada & 46 & 21,1 & 172 & 78,9 & & & \\
\hline \multirow[t]{4}{*}{4} & $\begin{array}{l}\text { - tidak } \\
\text { atopi }\end{array}$ & 24 & 3,6 & 637 & 96,4 & & & \\
\hline & $\begin{array}{l}\text { ayah dan } \\
\text { ibu }\end{array}$ & & & & & 0,167 & - & - \\
\hline & - Ada & 3 & 16,7 & 15 & 83,3 & & & \\
\hline & - tidak & 67 & 7,8 & 794 & 92,2 & & & \\
\hline
\end{tabular}

Hubungan karakteristik subjek penelitian dengan prevalens asma

Karakteristik subjek penelitian berupa berat badan lahir rendah merupakan faktor risiko untuk timbulnya asma. Kejadian asma pada anak dengan berat badan lahir < 2500 gram adalah 18,5\% lebih besar dibandingkan kejadian asma pada anak dengan berat badan lahir $\geq 2500$ gram yaitu $5,4 \%$. Perbedaan ini signifikan dengan nilai $p<0,05$. Karakteristik jenis kelamin, status gizi, jumlah saudara dan tingkat pendidikan ibu tidak bermakna secara statistik sebagai faktor risiko asma $(p>0,05)$ (tabel 3$)$.

Tabel 3. Karakteristik subjek penelitian dihubungkan dengan prevalens asma $(n=879)$

\begin{tabular}{|c|c|c|c|c|c|c|c|c|}
\hline \multirow{2}{*}{ No } & \multirow{2}{*}{ Variabel } & \multicolumn{2}{|c|}{ Asma } & \multicolumn{2}{|c|}{ Tidak asma } & \multirow{2}{*}{$\mathbf{p}$} & \multirow{2}{*}{ OR } & \multirow{2}{*}{ Cl } \\
\hline & & $\mathrm{n}$ & $\%$ & $\mathrm{~N}$ & $\%$ & & & \\
\hline \multirow[t]{3}{*}{1} & $\begin{array}{l}\text { Jenis } \\
\text { kelamin }\end{array}$ & & & & & 0,811 & - & - \\
\hline & - Laki-laki & 36 & 8,2 & 404 & 91,8 & & & \\
\hline & Perempuan & 34 & 7,7 & 405 & 92,3 & & & \\
\hline \multirow[t]{4}{*}{2} & Status gizi & & & & & 0,726 & - & - \\
\hline & Underweight & 18 & 8 & 206 & 92 & & & \\
\hline & - Normal & 49 & 8,2 & 552 & 91,8 & & & \\
\hline & Overweight & 1 & 2,9 & 33 & 97,1 & & & \\
\hline \multirow[t]{2}{*}{3} & $\begin{array}{l}\text { - Obesitas } \\
\text { Jumlah }\end{array}$ & 2 & 10 & 18 & 90 & & & \\
\hline & $\begin{array}{l}\text { saudara } \\
-\leq 2 \\
\text { saudara } \\
->2\end{array}$ & 47 & 8 & 541 & 92 & 0,963 & - & - \\
\hline \multirow[t]{4}{*}{4} & $\begin{array}{l}\text { saudara } \\
\text { Tingkat } \\
\text { pendidikan }\end{array}$ & 23 & 7,9 & 268 & 92,1 & & & \\
\hline & ibu & & & & & 0,237 & - & - \\
\hline & - Rendah & 57 & 7,5 & 700 & 92,5 & & & \\
\hline & - tinggi & 13 & 10,7 & 109 & 89,3 & & & \\
\hline 5 & $\begin{array}{l}\text { Berat badan } \\
\text { lahir } \\
\quad-<2500 \\
\text { gram } \\
\quad-\geq 2500 \\
\text { gram }\end{array}$ & 10 & $\begin{array}{c}18,5 \\
7,3\end{array}$ & 44 & $\begin{array}{l}81,5 \\
92,7\end{array}$ & 0,000 & 2,898 & $\begin{array}{l}1,39 \\
6,04\end{array}$ \\
\hline
\end{tabular}

\section{Hubungan faktor lingkungan dengan kejadian} asma

kurang mengkonsumsi sayuran merupakan faktor risiko untuk kejadian asma dan pemberian ASI merupakan faktor protektif untuk timbulnya asma ( $\mathrm{p}<$ $0,05)$, sedangkan konsumsi makanan cepat saji, konsumsi coklat, es dan MSG secara statistik tidak memiliki hubungan yang bermakna dengan kejadian asma $(p<0,05)$.

pemberian parasetamol setidaknya 1 kali per lan merupakan faktor risiko untuk kejadian asma ( $p$ $<0,05)$, sedangkan pemberian antibiotik sampai usia 12 bulan secara statistik tidak memiliki hubungan yang bermakna dengan kejadian asma $(p<0,05)$.

adanya kontak dengan anjing, kucing dan unggas dalam 12 bulan terakhir serta kontak dengan anjing dan kucing dalam 12 bulan pertama kehidupan secara statistik tidak memiliki hubungan yang bermakna dengan kejadian asma $(p>0,05)$.

kebiasaan merokok pada ibu dan kebiasaan merokok pada ibu sebelum anak berusia 1 tahun merupakan faktor yang bermakna untuk timbunya asma $(p<0,05)$, sedangkan kebiasaan merokok pada ayah secara statistik tidak memiliki hubungan yang bermakna dengan kejadian asma $(p>0,05)$. aktifitas keseharian kurang, bahan bakar memasak, lingkungan dilalui truk, memakai kipas angin, karpet dan kasur kapuk secara statistik tidak memiliki hubungan yang bermakna dengan kejadian asma $(p>0,05)$. 
Tabel 4. Hubungan faktor diet dengan kejadian asma $(n=879)$

\begin{tabular}{|c|c|c|c|c|c|c|c|c|}
\hline \multirow{2}{*}{ No } & \multirow{2}{*}{ Variabel } & \multicolumn{2}{|c|}{ Asma } & \multicolumn{2}{|c|}{ Tidak asma } & \multirow{2}{*}{$\mathbf{p}$} & \multirow{2}{*}{ OR } & \multirow{2}{*}{$\mathrm{Cl}$} \\
\hline & & $\mathrm{n}$ & $\%$ & $\mathrm{~N}$ & $\%$ & & & \\
\hline \multirow[t]{3}{*}{1} & Konsumsi makanan cepat saji & & & & & 0,742 & - & - \\
\hline & $-\mathrm{Ya}$ & 17 & 7,5 & 211 & 92,5 & & & \\
\hline & - Tidak & 53 & 8,1 & 598 & 91,9 & & & \\
\hline \multirow[t]{3}{*}{2} & Kurang makan sayuran & & & & & 0,017 & 1,86 & $1,11-3,16$ \\
\hline & $-Y a$ & 25 & 11,8 & 186 & 88,2 & & & \\
\hline & - Tidak & 45 & 6,7 & 623 & 93,3 & & & \\
\hline \multirow[t]{3}{*}{3} & Konsumsi coklat & & & & & 0,820 & - & - \\
\hline & $-\geq 3 \mathrm{x} /$ minggu & 25 & 7,7 & 300 & 92,3 & & & \\
\hline & $-<3 x /$ minggu & 45 & 8,1 & 509 & 91,9 & & & \\
\hline \multirow[t]{3}{*}{4} & Konsumsi es & & & & & 0,831 & - & - \\
\hline & $-\geq 3 \times /$ minggu & 31 & 7,8 & 369 & 92,3 & & & \\
\hline & $-<3 x /$ minggu & 39 & 8,1 & 440 & 91,9 & & & \\
\hline \multirow[t]{3}{*}{5} & Konsumsi MSG & & & & & 0,084 & - & - \\
\hline & $-\geq 3 \times /$ minggu & 34 & 9,9 & 308 & 90,1 & & & \\
\hline & $-<3 x /$ minggu & 36 & 6,7 & 501 & 93,3 & & & \\
\hline \multirow[t]{3}{*}{6} & Pemberian ASI & & & & & 0,019 & 0,429 & $0,21-0,89$ \\
\hline & $-\mathrm{Ya}$ & 60 & 7,4 & 755 & 92,6 & & & \\
\hline & - Tidak & 10 & 15,6 & 54 & 84,4 & & & \\
\hline \multirow[t]{3}{*}{7} & Pemberian parasetamol & & & & & 0,000 & 2,75 & $1,67-4,50$ \\
\hline & - setidaknya 1x/bulan & 38 & 13,5 & 244 & 86,5 & & & \\
\hline & - setidaknya $1 \mathrm{x} / \mathrm{th} / \mathrm{tidak}$ & 32 & 5,4 & 565 & 94,6 & & & \\
\hline \multirow[t]{3}{*}{8} & Pemberian antibiotik & & & & & 0,254 & - & - \\
\hline & $-\mathrm{Ya}$ & 48 & 8,8 & 499 & 91,2 & & & \\
\hline & - Tidak & 22 & 6,6 & 310 & 93,4 & & & \\
\hline \multirow[t]{3}{*}{9} & $\begin{array}{l}\text { Kontak dengan anjing } 12 \text { bln } \\
\text { terakhir }\end{array}$ & & & & & 0,375 & - & - \\
\hline & $-\mathrm{Ya}$ & 3 & 5,7 & 50 & 94,3 & & & \\
\hline & - Tidak & 67 & 8,1 & 759 & 91,9 & & & \\
\hline \multirow[t]{3}{*}{10} & $\begin{array}{l}\text { Kontak dengan anjing } 12 \text { bulan } \\
\text { pertama kehidupan }\end{array}$ & & & & & 0,367 & - & - \\
\hline & $-\mathrm{Ya}$ & 2 & 5 & 38 & 95 & & & \\
\hline & - Tidak & 68 & 8,1 & 771 & 91,9 & & & \\
\hline 11 & $\begin{array}{l}\text { Kontak dengan kucing } 12 \mathrm{bln} \\
\text { terakhir }\end{array}$ & & & & & 0,411 & - & - \\
\hline & $-\mathrm{Ya}$ & 18 & 6,8 & 246 & 93,2 & & & \\
\hline & - Tidak & 52 & 8,5 & 615 & 91,5 & & & \\
\hline 12 & $\begin{array}{l}\text { Kontak dengan kucing } 12 \text { bulan } \\
\text { pertama kehidupan }\end{array}$ & & & & & 0,844 & - & - \\
\hline & $-Y a$ & 14 & 8,3 & 154 & 91,7 & & & \\
\hline & - Tidak & 56 & 7,9 & 655 & 92,1 & & & \\
\hline 13 & $\begin{array}{l}\text { Kontak dengan unggas } 12 \text { bulan } \\
\text { terakhir }\end{array}$ & & & & & 0,167 & - & - \\
\hline & $-\mathrm{Ya}$ & 13 & 5,8 & 211 & 94,2 & & & \\
\hline & - Tidak & 57 & 8,7 & 598 & 91,3 & & & \\
\hline 14 & Kebiasaan merokok ayah & & & & & 0,746 & - & - \\
\hline & $-\mathrm{Ya}$ & 49 & 7,8 & 581 & 92,2 & & & \\
\hline & - Tidak & 21 & 8,4 & 228 & 91,6 & & & \\
\hline 15 & Kebiasaan merokok ibu & & & & & 0,032 & 4,025 & $\begin{array}{l}1,26- \\
12,83\end{array}$ \\
\hline & $-\mathrm{Ya}$ & 4 & 25 & 12 & 75 & & & \\
\hline & - Tidak & 66 & 7,6 & 797 & 92,4 & & & \\
\hline 16 & $\begin{array}{l}\text { Kebiasaan merokok ibu satu tahun } \\
\text { pertama }\end{array}$ & & & & & 0,001 & 3,886 & $\begin{array}{l}1,69- \\
8,94\end{array}$ \\
\hline & $-Y a$ & 8 & 23,5 & 26 & 76,5 & & & \\
\hline & - Tidak & 62 & 7,3 & 783 & 92,7 & & & \\
\hline 17 & Aktifitas keseharian kurang & & & & & 0,551 & - & - \\
\hline & - Ya & 66 & 7,9 & 773 & 92,1 & & & \\
\hline & - Tidak & 4 & 10 & 36 & 90 & & & \\
\hline 18 & Bahan bakar memasak & & & & & 0,795 & - & - \\
\hline & - Listrik & 1 & 20 & 4 & 80 & & & \\
\hline
\end{tabular}




\begin{tabular}{|c|c|c|c|c|c|}
\hline \multicolumn{4}{|c|}{ - Gas } & 18 & 8 \\
\hline \multirow{5}{*}{19} & \multicolumn{3}{|l|}{ - Minyak tanah } & 44 & 7 , \\
\hline & \multicolumn{5}{|c|}{ Lingkungan dilalui truk } \\
\hline & \multicolumn{2}{|l|}{ - Sering } & \multicolumn{3}{|c|}{30} \\
\hline & \multicolumn{2}{|l|}{ - Jarang } & \multicolumn{3}{|c|}{40} \\
\hline & \multicolumn{2}{|l|}{ - Tidak } & \multicolumn{3}{|c|}{23} \\
\hline \multirow[t]{3}{*}{20} & \multicolumn{5}{|c|}{ Memakai kipas angin } \\
\hline & \multicolumn{2}{|l|}{ - Ya } & \multicolumn{3}{|c|}{47} \\
\hline & \multicolumn{2}{|l|}{ - Tidak } & \multicolumn{3}{|c|}{23} \\
\hline \multirow[t]{3}{*}{21} & \multicolumn{5}{|l|}{ Memakai karpet } \\
\hline & \multicolumn{2}{|l|}{ - Ya } & \multicolumn{3}{|c|}{29} \\
\hline & \multicolumn{2}{|l|}{ - Tidak } & \multicolumn{3}{|c|}{41} \\
\hline \multirow[t]{3}{*}{22} & \multicolumn{5}{|c|}{ Memakai kasur kapuk } \\
\hline & \multicolumn{2}{|l|}{ - Ya } & \multicolumn{3}{|c|}{47} \\
\hline & \multicolumn{2}{|l|}{ - Tidak } & \multicolumn{3}{|c|}{23} \\
\hline \multicolumn{6}{|c|}{$\begin{array}{l}\text { Analisis multivariat (regresi logistic) terhada } \\
\text { faktor-faktor yang mempengaruhi kejadian asma } \\
\text { Berdasarkan hasil analisis regresi logistik } \\
\text { terlihat bahwa faktor yang paling domina } \\
\text { berpengaruh terhadap kejadian asma adalah atop } \\
\text { ayah atau ibu, diikuti faktor berat badan lahir da } \\
\text { kebiasaan merokok pada ibu serta pemberian oba } \\
\text { parasetamol.Sedangkan pemberian ASI dan papara } \\
\text { terhadap unggas merupakan faktor protektif terhada } \\
\text { kejadian asma (tabel 5). }\end{array}$} \\
\hline \multicolumn{6}{|c|}{$\begin{array}{l}\text { Tabel 5. Faktor dominan yang mempengaruhi kejadia } \\
\text { asma }\end{array}$} \\
\hline \multirow{2}{*}{ No } & \multirow{2}{*}{ Variabel } & \multicolumn{4}{|c|}{ Model VI } \\
\hline & & $p$ & B & OR & $\begin{array}{c}95 \% \\
\mathrm{Cl}\end{array}$ \\
\hline 1 & $\begin{array}{l}\text { atopi ayah } \\
\text { atau ibu }\end{array}$ & 0.000 & 1,945 & 6,993 & $\begin{array}{l}4,019- \\
12,166\end{array}$ \\
\hline 2 & $\begin{array}{l}\text { kurang } \\
\text { makan } \\
\text { sayuran }\end{array}$ & 0,052 & 0,575 & 1,777 & $\begin{array}{l}0,994- \\
3,177\end{array}$ \\
\hline 3 & $\begin{array}{l}\text { konsumsi } \\
\text { MSG }\end{array}$ & 0,070 & 0,505 & 1,657 & $\begin{array}{l}0,959- \\
2,861\end{array}$ \\
\hline 4 & $\begin{array}{l}\text { pemberian } \\
\text { obat } \\
\text { parasetamol }\end{array}$ & 0,002 & 0,837 & 2,310 & $\begin{array}{l}1,394- \\
3,956\end{array}$ \\
\hline 5 & $\begin{array}{l}\text { berat badan } \\
\text { lahir }\end{array}$ & 0.000 & 1,581 & 4,862 & $\begin{array}{l}2,091- \\
11,304\end{array}$ \\
\hline 6 & $\begin{array}{l}\text { pemberian } \\
\text { ASI }\end{array}$ & 0,013 & 1,055 & 0,348 & $\begin{array}{l}0,152- \\
0,799\end{array}$ \\
\hline 7 & $\begin{array}{l}\text { kontak } \\
\text { dengan } \\
\text { unggas }\end{array}$ & 0,04 & $\begin{array}{c}- \\
0,725\end{array}$ & 0,484 & $\begin{array}{l}0,243- \\
0,966\end{array}$ \\
\hline 8 & $\begin{array}{l}\text { kebiasaan } \\
\text { merokok ibu }\end{array}$ & 0,01 & 1,271 & 3,566 & $\begin{array}{l}1,364- \\
9,325\end{array}$ \\
\hline
\end{tabular}

\section{Pembahasan}

Prevalens asma pada penelitian ini didapatkan sebesar 8,0\% (70 dari 879 orang). Angka ini lebih tinggi dari data ISAAC di Indonesia tahun 1998 untuk kelompok umur yang sama yaitu $4,1 \%$, terjadi peningkatan sebesar $95,12 \% .^{3}$ Hasil penelitian ini sama dengan yang didapatkan Tanjung di Palembang pada kelompok umur yang sama tahun 2008, juga sebesar $8,0 \%$.

Pengaruh faktor genetik terhadap kejadian asma diidentifikasi melalui adanya riwayat atopi yaitu asma, rinitis alergi dan eksim pada orang tua. Pada analisis bivariat, adanya riwayat atopi ayah akan meningkatkan kejadian asma 3,18 kali dibandingkan anak yang ayahnya tidak ada riwayat atopi $(p=0,000$ :

$187 \quad 91,2$

$529 \quad 92,3$

29290,7

$517 \quad 92,8$

28392,5

$526 \quad 91,8$

$283 \quad 92,5$

$323 \quad 91,8$

$486 \quad 92,2$

60592,8

$204 \quad 89,9$

$95 \% \mathrm{Cl}=1,72-5,85)$, riwayat atopi ibu 5,2 kali $(\mathrm{p}=0,000: 95 \% \mathrm{Cl}=3,14-8,68)$ dan riwayat atopi salah satu orang tua 7,1 kali $(p=0,000: 95 \% \mathrm{Cl}=4.21$ 11.96), sedangkan riwayat atopi pada kedua orang tua tidak memperlihatkan hubungan yang bermakna dengan kejadian asma $(p=0,725)$. Pada analisis multivariat ternyata faktor atopi yang bermakna mempengaruhi kejadian asma hanya atopi pada salah satu orang tua (riwayat atopi ayah atau ibu) $(p=0,000$ $\mathrm{OR}=7: 95 \% \mathrm{Cl} 4,0-12,2)$.

Peran faktor atopi telah dibuktikan oleh banyak peneliti.Faktor atopi terdapat $80 \%$ pada anak yang menderita asma. Atopi yang muncul pada usia dini terutama dalam 3 tahun pertama kehidupan memiliki potensi untuk berkembang menjadi asma. Bila kedua orang tua menderita penyakit alergi (atopi), maka kemungkinan $60 \%$ anaknya akan menderita atopi pula. Bila hanya satu dari orang tua yang menderita atopi maka kemungkinannya $40 \%$ menderita atopi dan bila kedua orang tua tidak menderita atopi maka hanya 15\% kemungkinan anaknya menderita atopi. Pengaruh genetik ibu lebih kuat terhadap kejadian asma dibanding genetik ayah. Risiko asma lebih besar pada anak dari ibu asma dibandingkan ayah yang menderita asma. ${ }^{15}$

Pada penelitian ini terlihat bahwa pengaruh atopi ayah dan ibu tidak bermakna untuk mempengaruhi asma, tidak seperti pada teori-teori sebelumnya.Hasil temuan ini mungkin disebabkan sampel yang ayah dan ibunya atopi hanya sedikit dan pada sampel dengan ayah dan ibunya memiliki riwayat atopi, sebagian besar atopinya adalah rinitis alergi (78\%), tidak didapatkan kedua orang tua dengan atopinya asma.

Berat badan lahir rendah berhubungan dengan fungsi pernafasan yang lebih buruk. Terdapat proses perkembangan inutero yang tidak dapat digantikan pada lingkungan post natal, hal ini menyebabkan fungsi respirasi yang lebih rendah dan peningkatan kecenderungan asma hingga dewasa. Pada penelitian ini pada analisis multivariat subjek yang memiliki berat badan lahir rendah memiliki risiko 4,87 kali ( $p=0,000 ; 95 \% \mathrm{Cl}$ 2,09-11,30) lebih besar untuk menderita asma dibandingkan subjek yang lahir dengan berat badan cukup atau lebih.

Penelitian sebelumnya tentang ASI ekslusif, menunjukkan pemberian ASI ekslusif berhubungan dengan penurunan risiko asma, diduga karena adanya efek imunomodulasi dan pencegah infeksi. ${ }^{16,17}$ Pada penelitian ini, pada analisis multivariat pemberian ASI paling tidak sampai usia 4 bulan akan menurunkan 
kejadian asma sebesar 35\% $(p=0,013 ; 95 \%$ Cl 0,15$0,80)$.

Pemberian parasetamol yang sering dapat meningkatkan risiko asma melalui penurunan kadarglutation paru. Pada penelitian ini dengan analisis multivariat didapatkan hasil yang sesuai, dimana anak yang sering (setidaknya sekali sebulan) mendapatkan parasetamol 2,3 kali lebih sering menderita asma dibandingkan anak yang lebih jarang diberikan parasetamol ( $\mathrm{p}=0,002 ; 95 \% \mathrm{Cl}=1,39-3,96)$. Newson mendapatkan pada data ISAAC bahwa setiap gram perkapita permakaian parasetamol akan meningkatkan kejadian asma $0,52 \%(p=0,0005 ; 95 \%$ $\mathrm{Cl} 0,44-0,59)$ pada anak 13-14 tahun dan $0,31 \%(\mathrm{p}=$ $0,001 ; 95 \% \mathrm{Cl} 0,14-0,48)$ pada anak 6-7 tahun. ${ }^{18}$

Kontak dengan unggas dalam 12 bulan terakhir tidak merupakan faktor risiko yang bermakna untuk menyebabkan asma pada penelitian ini $(p=0,167)$. Tetapi pada analisis multivariat paparan terhadap unggas ini justru merupakan faktor protektif terhadap asma ( $p=0,04$, OR 0,48; 95\% Cl 0,24-0,97). Hal ini mungkin juga dipengaruhi seberapa sering anak kontak dengan unggas tersebut, jumlah unggas, jarak antara kandang dengan rumah dan kebersihan kandang yang tidak tercakup dalam penelitian ini.

Kebiasaan merokok pada ibu berperan dalam meningkatkan prevalens asma $(p=0,032$ OR $=4,025$; $95 \% \mathrm{Cl} 1,263-12,829)$ dan kebiasaan ibu merokok dalam satu tahun pertama kehidupan subjek juga bermakna dalam meningkatkan prevalens asma $(p=0,001$ OR=3,886; 95\% Cl 1,688-8,943). Namun dari analisis multivariat yang mempengaruhi kejadian asma hanya kebiasaan merokok pada ibu dalam 12 bulan terakhir ( $p=0,001$, OR 3,57; $95 \% \mathrm{Cl} 1,36-9,33)$. $\mathrm{Hal}$ ini menunjukkan pentingnya pengaruh paparan asap rokok pada sistim pernafasan. Namun kebiasaan merokok pada ayah tidak memiliki hubungan yang bermakna dengan kejadian asma $(p=0,746)$. Hal ini mungkin disebabkan secara umum anak akan lebih sering kontak dengan ibu dibandingkan ayah, sehingga lama paparan dengan asap rokok dari ayah akan berkurang.

Kurang sayuran berhubungan dengan kejadian asma yang lebih besar $(p=0,017$, $O R=1,86$ : $95 \% \mathrm{Cl} 1,11-3,16)$, namun setelah dilakukan analisis multivariat hubungan ini menjadi tidak bermakna $(p=0,052)$. Konsumsi makanan cepat saji juga tidak menunjukkan hubungan yang bermakna dengan kejadian asma $(p=0,724)$. Kurang sayuran menyebabkan kurangnya faktor-faktor protektif yang dapat mencegah asma seperti vitamin A, C, E, beta karoten dan selenium, sedangkan konsumsi makanan cepat saji menyebabkan meningkatnya asupan lemak tidak jenuh terutama omega 6 PUFA yang dapat meningkatkan pembentukan sitokin pro inflamasi dan lgE. ${ }^{19-21}$ Faktor-faktor protektif antioksidan dan peningkatan faktor pemicu asupan lemak tidak jenuh ini nampaknya tidak pada tingkat yang berpengaruh. Untuk membuktikan lebih lanjut dibutuhkan penelitian yang menghubungkan kadar nutrien-nutrien tersebut dalam tubuh dengan gejala asma.

Faktor risiko lainnya yang kurang berperan dengan kejadian asma seperti status gizi, jumlah saudara, pendidikan ibu, konsumsi makanan cepat saji, coklat, es dan MSG, pemberian antibiotik sebelum usia 1 tahun, kontak dengan anjing dan kucing, aktifitas keseharian, bahan bakar memasak, paparan lalu lintas, memakai kipas angin, karpet dan kasur kapuk.

\section{Kesimpulan}

Prevalens asma pada murid SD usia 6-7 tahun di Kota Padang berdasarkan kuisioner ISAAC sebesar $8 \%$. Berdasarkan analisis multivariat regresi logistik faktorfaktor yang bermakna untuk mempengaruhi timbulnya asma berurutan mulai yang paling dominan adalah atopi ayah atau ibu, diikuti faktor berat badan lahir dan kebiasaan merokok pada ibu serta pemberian obat parasetamol.Sedangkan pemberian ASI dan kontak dengan unggas merupakan faktor protektif terhadap kejadian asma.

\section{Daftar Pustaka}

1. Smyth RL. Asthma: a major pediatric health issue. Resper Res 2002;3 suppl 1:S3-7.

2. MMWR. Measuring childhood asthma prevalence before and after the 1997 redesign of the national health interview survey-united state 2000; 49:90811.

3. ISAAC Steering Committee. Worldwide variations in prevalence of asthma symptoms: the International Study of Asthma and Allergies in Childhood (ISAAC). Eur Respir J 1998; 12:31535.

4. Asher MI, Grant C. Epidemiology of Asthma. Dalam: Chernick V, Boat TF, Wilmott RW, Bush $A$, penyunting. Kendig's disorders of the respiratory tract in children. Edisi ketujuh. Philadelphia: Elsevier Inc; 2006. h. 762-85.

5. Environmental questionnaire instructions and hypotheses, 6-7 year age group. Didapat dari: www.isaac.auckland.html.

6. Pickett M. Chocolate and asthma aggravation. Harvard Health Publication-Harvard Medical School. Didapat dari: www.msn.com

7. Lin YZ, Hsieh KH. Asthma induced by ice water ingestion in ethnic Chinese asthmatic children: a challenge. Pediatr Allergy Immunol 2007;8:11-6.

8. Wilson NM, Chudry N, Silverman M. Role of aesophagus in asthma induced by the ingestion of ice and acid. Thorax 1987;42:506-10.

9. Stevenson DD. Monosodium glutamate and asthma. J Nutr 2000;130:1067S-73S.

10. Woessner KM, Simon RA, Stevenson DD. Monosodium glutamate sensitivity in asthma. $J$ Allergy Clin Immunol 1999;104:305-10.

11. Lutsky I, Teichtahl H, Bar-Sela S. Occupational asthma due to poultry mites. J Allergy Clin Immunol 1984; 73:56-60.

12. Teoh PC, Tan WC, Oon CJ, Lui KF. Prick skin test in bronchial asthma and their correlation with the specific serum IgE levels. Singapore Med J 1977;18:228-31.

13. Getzshe PC, Johansen HK. House dust mite control measures for asthma (review). Cochrane Database of Systematic Reviews 2008, Issue 2. Art. No: CD001187. DOI: 10.1002/14651858.CD001187.pub3.

14. Tanjung M. Prevalensi dan faktor risiko asma pada anak sekolah dasar usia 6-7 tahun di Palembang berdasarkan kuisioner international study of asthma and allergies in childhood. [tesis]. Palembang: Bagian IImu Kesehatan Anak FK Unsri, 2008.

15. von Mutius E. Nocolai T. Familial aggregation of asthma in a South Bavarian population. Am J Respir Crit Care Med 1996;153:1266-72.

16. Oddy $\mathrm{WH}$, Holt PG, Sly PD, dkk. Association between breast feeding and asthma in 6 year old 
children: findings o a prospective birth cohort study. BMJ 1999; 319:815-9.

17. Gdalevich M, Mimouni D, Mimouni M. Breastfeeding and the risk of bronchial asthma in childhood: a systematic review with meta-analysis of prospective studies. J Pediatr 2001; 139:261-6.

18. Newson RB, Shaheen SO, Chinn S, Burney PGJ. Paracetamol sales and atopic disease in children and adults: an ecological analysis. Eur Respir J 2000; 16:817-23.

19. Hijazi N, Abalkhail B, Seaton A. Diet and childhood asthma in a society in transition. A study in urban and rural Saudi Arabia. Thorax 2000; 55:775-9.
20. Forastiere $F$, Pistelli $R$, Sestini $P$, dkk. Consumption of fresh fruit rich in vitamin $C$ and wheezing symptoms in children. SIDRIA Collaborative group, Italy (Italian Study on Respiratory Disorders in Children and the Environment). Thorax 2000; 55:283-8.

21. Farchi S, Forastiere F, Agabiti N, dkk. Dietary faktor associated with wheezing and allergic rhinitis in children. Eur Respir J 2003; 22:772-80. 